\title{
Identification of ovule transcripts from the Apospory-Specific Genomic Region (ASGR)-carrier chromosome
}

\author{
Yajuan Zeng ${ }^{\dagger}$, Joann Conner ${ }^{\dagger}$ and Peggy Ozias-Akins ${ }^{*}$
}

\begin{abstract}
Background: Apomixis, asexual seed production in plants, holds great potential for agriculture as a means to fix hybrid vigor. Apospory is a form of apomixis where the embryo develops from an unreduced egg that is derived from a somatic nucellar cell, the aposporous initial, via mitosis. Understanding the molecular mechanism regulating aposporous initial specification will be a critical step toward elucidation of apomixis and also provide insight into developmental regulation and downstream signaling that results in apomixis. To discover candidate transcripts for regulating aposporous initial specification in P. squamulatum, we compared two transcriptomes derived from microdissected ovules at the stage of aposporous initial formation between the apomictic donor parent, $P$. squamulatum (accession PS26), and an apomictic derived backcross 8 ( $\left.\mathrm{BC}_{8}\right)$ line containing only the AposporySpecific Genomic Region (ASGR)-carrier chromosome from P. squamulatum. Toward this end, two transcriptomes derived from ovules of an apomictic donor parent and its apomictic backcross derivative at the stage of apospory initiation, were sequenced using 454-FLX technology.

Results: Using 454-FLX technology, we generated 332,567 reads with an average read length of 147 base pairs (bp) for the PS26 ovule transcriptome library and 363,637 reads with an average read length of 142 bp for the $\mathrm{BC}_{8}$ ovule transcriptome library. A total of 33,977 contigs from the PS26 ovule transcriptome library and 26,576 contigs from the $\mathrm{BC}_{8}$ ovule transcriptome library were assembled using the Multifunctional Inertial Reference Assembly program. Using stringent in silico parameters, 61 transcripts were predicted to map to the ASGR-carrier chromosome, of which 49 transcripts were verified as ASGR-carrier chromosome specific. One of the alien expressed genes could be assigned as tightly linked to the ASGR by screening of apomictic and sexual $F_{1}$ s. Only one transcript, which did not map to the ASGR, showed expression primarily in reproductive tissue.

Conclusions: Our results suggest that a strategy of comparative sequencing of transcriptomes between donor parent and backcross lines containing an alien chromosome of interest can be an efficient method of identifying transcripts derived from an alien chromosome in a chromosome addition line.
\end{abstract}

\section{Background}

Apomixis, asexual reproduction through seed, is widespread among flowering plant families, but low in its frequency of occurrence [1]. Different from sexual reproduction, apomictically derived embryos develop autonomously from unreduced ovular cells instead of through fertilization of a reduced egg by a sperm. Therefore, the progeny of an apomictic plant are genetically

\footnotetext{
* Correspondence: pozias@uga.edu

† Contributed equally

Department of Horticulture, The University of Georgia Tifton Campus, Tifton, GA, 31973, USA
}

identical to the maternal plant $[2,3]$. This trait can be used as an advanced breeding tool in agriculture since it would enable fixation of hybrid vigor and seed propagation of desirable genotypes [4-7]. No major agriculturally important crop possesses this trait [8-10]. Introgression of apomixis into crops through crossing has been impeded by factors such as polyploidy and incompatibility [9]. Therefore, discovery of genetic mechanisms underlying apomixis will be crucial for manipulation of apomixis for introduction into target crops.

Apomixis has been classified into two types and three developmental pathways: gametophytic apomixis,

\section{Biomed Central}


including apospory and diplospory, and sporophytic apomixis, which is also known as adventitious embryony [2]. In sporophytic apomixis, an embryo forms directly from an ovular cell and coexists with the zygotic embryo. For gametophytic apomixis, the embryo develops from an unreduced egg in an embryo sac derived through mitosis of either a somatic nucellar cell (apospory) or the megaspore mother cell (diplospory). In apospory, meiosis either does not complete or its products degenerate while aposporous initials (AIs) develop from one or more somatic nucellar cells. Both genotypes chosen for the present study are aposporous with the trait conferred by genetic elements from Pennisetum squamulatum. Aposporous P. squamulatum has fournucleate embryo sacs that lack antipodals [10]. Apospory in this species is inherited as a dominant Mendelian trait [11] and is associated with an approximately 50 $\mathrm{Mb}$, heterochromatic and hemizygous chromosomal region designated the Apospory-Specific Genomic Region (ASGR), [12,13].

Many transcriptional approaches to discover the regulatory mechanisms and downstream effects associated with apomixis in many species have been undertaken. In Brachiaria, differential display applied to apomictic and sexual ovaries at anthesis yielded two apomixis-specific fragments [14] while a study on earlier sporogenesis and gametogenesis stages identified eleven differentially expressed fragments [15]. In Paspalum notatum, three expressed sequence tags (ESTs), all highly similar in sequence, showed differential expression in flowers between apomictic and sexual $F_{1}$ individuals after apospory initiation [16]. An additional 65 genes were identified as differentially expressed between sexual and aposporous plants [17]. cDNA-AFLP analysis in Paspalum simplex yielded transcripts linked to the apomixiscontrolling locus (ACL). Many of these linked fragments showed stop codons and frameshift mutations, suggesting that they are pseudogenes [18]. cDNA-AFLP was also applied to identify apomixis candidate genes in Poa pratensis where 179 transcript-derived fragments from spikelets showed qualitative and quantitative expression differences between apomictic and sexual genotypes [19]. The full-length sequences of two genes of interest, PPSERK (SOMATIC EMBRYOGENESIS RECEPTORLIKE KINASE) and APOSTART were obtained and their temporal and spatial expression patterns were assessed by reverse transcription polymerase chain reaction (RTPCR) and in situ hybridization, respectively. While neither one of these two candidate genes showed apomixis- or sexual-specific expression, quantitative differences in expression between apomictic and sexual genotypes were observed [20].

One apomixis-specific gene was identified from a Panicum maximum ovule cDNA library and shown to be expressed in both aposporous initials and embryos at four days after anthesis [21,22]. Additional genes have been identified in Panicum through microarray and quantitative RT-PCR analysis [23]. In Pennisetum ciliare, differential display and suppression subtractive hybridization were used to identify gene expression differences in ovaries of sexual and apomictic accessions [24,25]. SuperSAGE, a high-throughput differential display approach, has been used to discover several hundred transcripts with heterochronic shifts in expression between apomictic and sexual ovules at multiple stages of development [26,27].

Formation of aposporous initials is the first and most critical event for occurrence of apospory. Because the initiation of sexual and apomictic pathways likely is activated by different signals [28], understanding the molecular mechanism underlying apospory initiation can provide insight into developmental regulation and downstream signaling that results in apomixis. In order to discover candidates for regulating aposporous initial specification in P. squamulatum, we compared two transcriptomes derived from microdissected ovules at the stage of aposporous initial (AI) formation between the apomictic donor parent, $P$. squamulatum, and its apomictic derivative backcross $8\left(\mathrm{BC}_{8}\right)$ containing a single $P$. squamulatum chromosome. Initially, a $P$. glaucum $\times$ P. squamulatum $\mathrm{F}_{1}$ was crossed with a $P$. glaucum $\times$ P. purpureum $\mathrm{F}_{1}$ and hybrid apomictic individuals with good male fertility were selected [29]. Subsequent backcrosses with tetraploid $P$. glaucum [30] yielded a $\mathrm{BC}_{8}$ line that was shown by FISH to contain only one chromosome from $P$. squamulatum. This single chromosome common to both apomictic $\mathrm{BC}_{8}$ and $P$. squamulatum was the ASGR-carrier chromosome based on the transmission of the trait of apomixis and linked molecular markers [31]. We hypothesize that candidate genes regulating aposporous initial specification and localized to the ASGR will function in both PS26 and $\mathrm{BC}_{8}$ at the same developmental stage and would be identical in sequence as they are related by descent.

The development and commercialization of new massively parallel sequencing platforms have made transcriptome sequencing faster and more affordable. One platform, developed by 454 Life Sciences Corporation, the 454 GS-FLX sequencer, is capable of producing 100 $\mathrm{Mb}$ of sequence data with an average read length of 250 bp per bead in a 7-h run [32]. Successful applications of these high-throughput sequencing technologies to transcriptome analysis have been reported [33-37]. Here we present expressed sequence tags (ESTs) generated by Roche 454 high-throughput sequencing technology from dissected ovule tissues staged for aposporous initial formation from two apomictic lines chosen for their 
common features of apospory and single shared chromosome. Alien chromosome (ASGR-carrier chromosome) expressed transcripts were identified and tested for ASGR linkage and tissue expression.

\section{Results}

Aposporous ovule-enriched cDNA samples for sequencing Ovules from PS26 and $\mathrm{BC}_{8}$ around the stage of aposporous initial formation were manually dissected from pistils (Figure 1). Three biological replicates of 40 ovules each were collected for both PS26 and $\mathrm{BC}_{8}$. The yield of total RNA from each replicate was approximately $20 \mathrm{ng}$ from which $15 \mathrm{ng}$ was used for one-round of T7 RNA polymerase-based RNA amplification. The average yield from one round of amplification was $90 \mu \mathrm{g}$. For each library, equal amounts of amplified RNA from each replicate were combined and $15 \mu \mathrm{g}$ amplified RNA was used for ds-cDNA synthesis. The majority of the dscDNA synthesized from amplified RNA was distributed in a size range from $200 \mathrm{bp}$ to $1000 \mathrm{bp}$ (Figure 2).

\section{Assembly of sequences from PS26 and $\mathrm{BC}_{8}$ aposporous ovules}

Two aposporous ovule transcriptomes, one from PS26 and the other from $\mathrm{BC}_{8}$, were sequenced using the high-throughput 454-FLX sequencer. The PS26 transcriptome library contained 332,567 reads with an average read length of 147 base pairs (bp) and the $\mathrm{BC}_{8}$ transcriptome library contained 363,637 reads with an average read length of $142 \mathrm{bp}$. Assembly by the Multifunctional Inertial Reference Assembly (MIRA) program [38] resulted in 33,977 contigs from the PS26 ovule transcriptome library and 26,576 contigs from the $\mathrm{BC}_{8}$ ovule transcriptome library (Additional file 1: PS26_MIRA.fasta, Additional file 2: BC8_MIRA.fasta). The number of reads per contig ranged from 1 to 759 in PS26 assemblies and 1 to 1661 in $\mathrm{BC}_{8}$ assemblies with the majority having less than 30 reads per assembly in both cases. The numbers of singletons in PS26 and $\mathrm{BC}_{8}$ libraries were 176 and 78 , respectively.

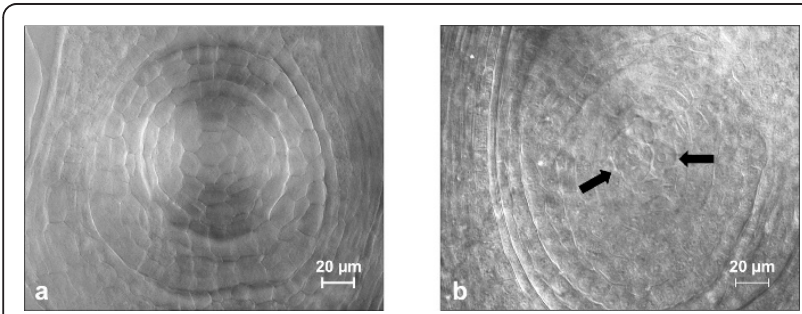

Figure 1 Microdissection and ovary clearing. a: cleared ovary showing no aposporous initials and prior to megasporogenesis. b: cleared ovary showing two aposporous initials, indicated by solid arrows.

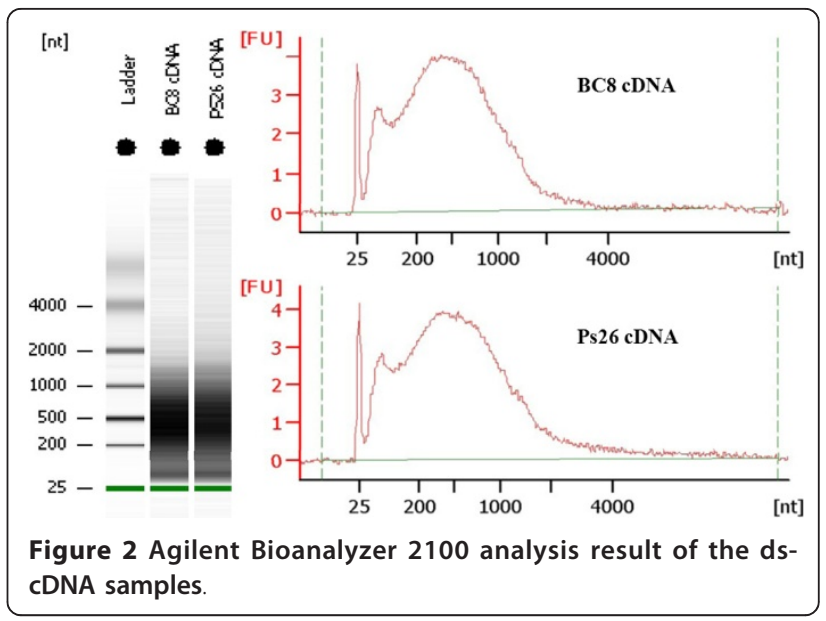

\section{Blast2GO}

Contigs from both transcriptome libraries were analyzed for biological functions using Blast2GO [39]. For both libraries, the use of $\mathrm{T} 7$ amplified RNA biased the sequencing data toward the 3' UTR region as shown by the BlastX results of the Blast2GO analysis. 5,730 PS26 contigs $(\sim 17 \%)$ and $4,833 \mathrm{BC}_{8}$ contigs $(\sim 18 \%)$ had hits against the nr database of NCBI with an E-value cut-off of $\mathrm{e}^{-06}$. For both libraries, $90 \%$ of the top BlastX hits were, in order, to Sorghum bicolor, Zea mays or Oryza sativa proteins. Blast2GO was able to fully annotate 4,400 PS26 contigs and 3,692 $\mathrm{BC}_{8}$ contigs (Figure 3).

To obtain additional functional data from the shorter reads, a study was initiated to test whether the most significant BlastN EST_other database hit (E-value cut off of $\mathrm{e}^{-20}$ ) could be used as a surrogate longer sequencing read for the $\mathrm{PS} 26 / \mathrm{BC}_{8}$ transcripts. Approximately 55\% $(14,518)$ of the $\mathrm{BC}_{8}$ contigs had an EST_OTHERS hit $\leq \mathrm{e}^{-20}$. Blast2GO analysis was used for the $\mathrm{BC}_{8}$ EST - OTHERS best matches and compared with Blast2GO mapping results for the 3692 annotated $\mathrm{BC}_{8}$ contigs. The majority $(84 \%)$ of the $\mathrm{BC}_{8}$ contigs had Blast2GO mapping data identical to the corresponding $\mathrm{BC}_{8} \mathrm{EST}_{-}-$ OTHERS mapping data while only $5 \%$ of the $\mathrm{BC}_{8}$ contigs had $>50 \%$ non-matching mapping data. Given the large percentage of identical and/or highly matching mapping data, a library of PS26_EST_OTHERS was also established using the same parameters as $\mathrm{BC}_{8} \mathrm{EST}_{-}-$ OTHERS. Approximately 53\% $(18,028)$ of the PS26 contigs had an EST_OTHERS hit $\leq \mathrm{e}^{-20}$. Blast2GO was able to fully annotate 12,462 PS26_EST_OTHERS contigs and 10,107 $\mathrm{BC}_{8}$ EST_OTHERS contigs.

A Fisher's Exact Test (using GOSSIP; [40]) was done to identify significant differences of expression data between the PS26 and $\mathrm{BC}_{8}$ libraries and the PS26_EST_OTHERS and $\mathrm{BC}_{8}$ EST_OTHERS libraries. At a false discovery rate $(\mathrm{FDR}) \leq 0.01,28 \mathrm{GO}$ terms were identified 


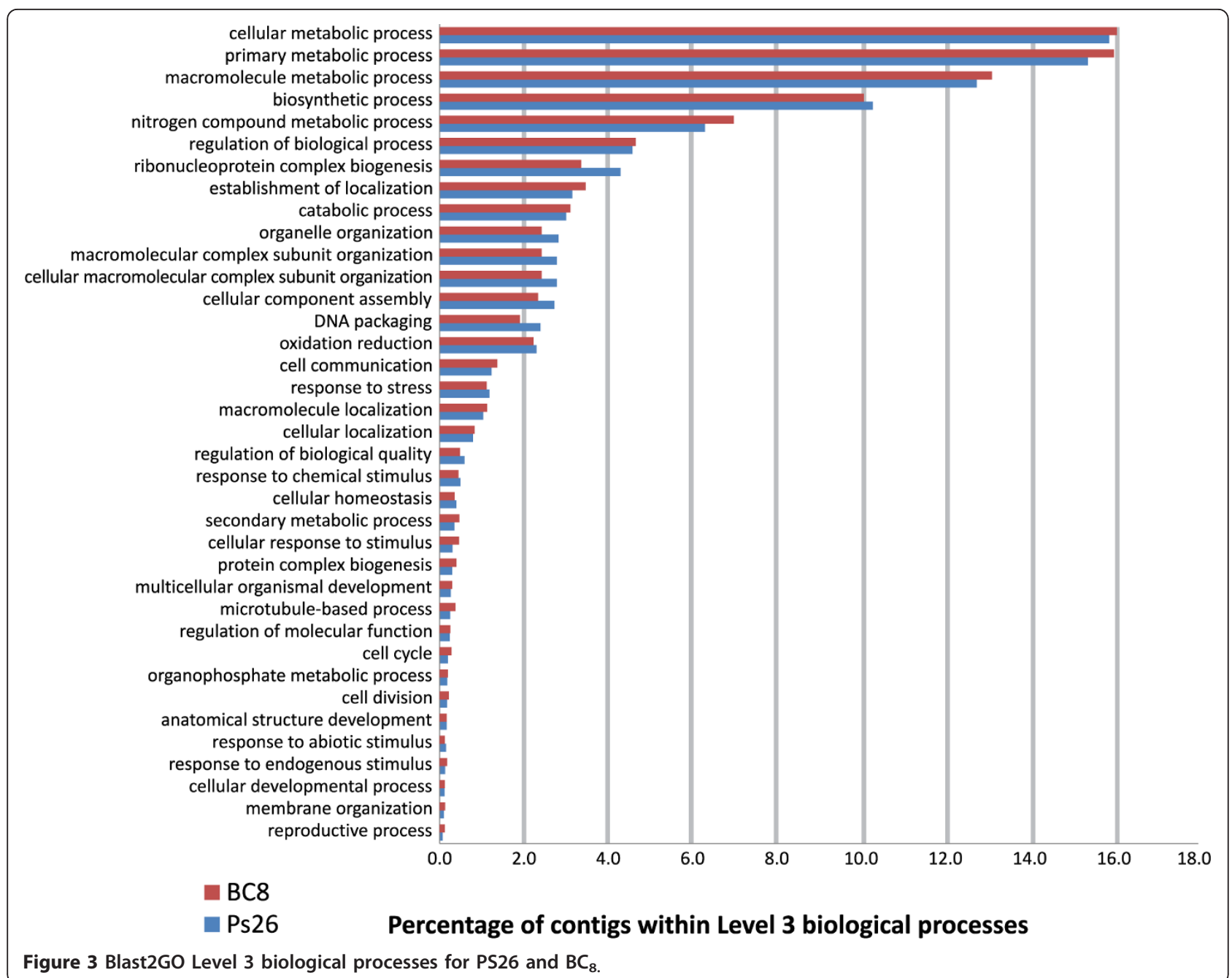

as different between the PS26 and $\mathrm{BC}_{8}$ libraries (Table 1). However, when the PS26_EST_OTHERS and $\mathrm{BC}_{8}$ EST_OTHERS libraries were compared at FDR $<0.05$ (at an FDR $\leq 0.01$ no significant results were returned), only 7 GO terms (ribosome, translation, ribosome biogenesis, ribonucleoprotein complex biogenesis, ribonucleoprotein complex, structural constituent of ribosome, cellular component biogenesis) were identified as differentially expressed between the two libraries (Table 1).

\section{In Silico identification of putative alien expressed transcripts}

When MIRA-assembled contigs from the two libraries were analyzed by BlastN with PS26 sequences as queries and $\mathrm{BC}_{8}$ sequences as the database, a total of 118 comparisons were obtained with $100 \%$ sequence identity across an overlapping region $\geq 100$ bp corresponding to 115 unique contigs from the PS26 database and 116 unique contigs from the $\mathrm{BC}_{8}$ database. The 118 PS26/
$\mathrm{BC}_{8}$ contigs were further analyzed by aligning the corresponding PS26 and $\mathrm{BC}_{8}$ contigs with each other, resulting in 61 inter-genotype contigs with no mismatches that were aligned. The average overlapping regions of the 61 inter-genotype contigs was 241 bp (ranging from $181 \mathrm{bp}$ to $419 \mathrm{bp}$ ) with an average number of 28 sequence reads. The remaining $\mathrm{PS} 26 / \mathrm{BC}_{8}$ contigs, while initially identified by BlastN as having $100 \%$ identity over a region $>100 \mathrm{bp}$, did not continue to share sequence similarity outside this region and therefore did not align over the whole contig.

\section{Mapping and predicted function of putative ASGR-carrier chromosome transcripts}

Up to four primer pairs per contig were used to test for linkage of the 61 contigs to the ASGR-carrier chromosome. Sequence characterized amplified region (SCAR) primer pairs were designed based on the PS26 contig sequence (Additional file 3, Table S1). After screening by PCR against PS26, IA4X $(4 \times P$. glaucum $)$, N37 
Table $1 \mathrm{GO}$ terms within the biological process category significantly over- or under-represented between the libraries.

\begin{tabular}{|c|c|c|c|c|c|}
\hline $\begin{array}{l}\text { GO TERM } \\
\text { ID }\end{array}$ & description & $\begin{array}{l}\text { Adjusted p-value } \\
\text { for Ps26_contigs } \\
\text { (FDR } \leq 0.01 \text { ) }\end{array}$ & $\begin{array}{l}\text { Over/Under } \\
\text { representation } \\
\text { Ps26_contigs }\end{array}$ & $\begin{array}{c}\text { Adjusted p-value for } \\
\text { Ps26_EST_OTHERS } \\
\text { contigs } \\
\text { (FDR } \leq 0.05)\end{array}$ & $\begin{array}{c}\text { Over/Under } \\
\text { representation } \\
\text { Ps26_EST_OTHERS } \\
\text { contigs }\end{array}$ \\
\hline GO:0005840 & ribosome & $1.90 \mathrm{E}-05$ & over & 1.10E-04 & over \\
\hline GO:0006412 & translation & $5.81 \mathrm{E}-06$ & over & 1.47E-04 & over \\
\hline GO:0042254 & ribosome biogenesis & $6.05 \mathrm{E}-06$ & over & $1.61 \mathrm{E}-04$ & over \\
\hline GO:0022613 & $\begin{array}{l}\text { ribonucleoprotein complex } \\
\text { biogenesis }\end{array}$ & 7.31E-06 & over & $1.61 \mathrm{E}-04$ & over \\
\hline GO:0030529 & ribonucleoprotein complex & $2.47 \mathrm{E}-05$ & over & $1.73 \mathrm{E}-04$ & over \\
\hline GO:0003735 & $\begin{array}{l}\text { structural constituent of } \\
\text { ribosome }\end{array}$ & $6.02 \mathrm{E}-06$ & over & 2.05E-04 & over \\
\hline GO:0044085 & cellular component biogenesis & $9.23 \mathrm{E}-06$ & over & $2.34 \mathrm{E}-04$ & over \\
\hline GO:0043228 & $\begin{array}{c}\text { non-membrane-bounded } \\
\text { organelle }\end{array}$ & 1.07E-05 & over & n.s. & \\
\hline GO:0043232 & $\begin{array}{l}\text { intracellular non-membrane- } \\
\text { bounded organelle }\end{array}$ & $1.07 \mathrm{E}-05$ & over & n.s. & \\
\hline GO:0005198 & structural molecule activity & 5.57E-05 & over & n.s. & \\
\hline GO:0034645 & $\begin{array}{c}\text { cellular macromolecule } \\
\text { biosynthetic process }\end{array}$ & $1.52 \mathrm{E}-04$ & over & n.s. & \\
\hline GO:0032559 & adenyl ribonucleotide binding & $1.24 \mathrm{E}-05$ & under & n.s. & \\
\hline GO:0005524 & ATP binding & $1.46 \mathrm{E}-05$ & under & n.s. & \\
\hline GO:0032553 & ribonucleotide binding & $1.60 \mathrm{E}-05$ & under & n.s. & \\
\hline GO:0032555 & purine ribonucleotide binding & $1.60 \mathrm{E}-05$ & under & n.s. & \\
\hline GO:0000166 & nucleotide binding & 5.36E-05 & under & n.s. & \\
\hline GO:0001882 & nucleoside binding & $5.56 \mathrm{E}-05$ & under & n.s. & \\
\hline GO:0017076 & purine nucleotide binding & 5.77E-05 & under & n.s. & \\
\hline GO:0001883 & purine nucleoside binding & 5.91E-05 & under & n.s. & \\
\hline GO:0030554 & adenyl nucleotide binding & $5.91 \mathrm{E}-05$ & under & n.s. & \\
\hline GO:0003824 & catalytic activity & $9.79 \mathrm{E}-05$ & under & n.s. & \\
\hline GO:0016740 & transferase activity & $1.38 \mathrm{E}-04$ & under & n.s. & \\
\hline GO:0006793 & phosphorus metabolic process & $1.67 \mathrm{E}-04$ & under & n.s. & \\
\hline GO:0006796 & phosphate metabolic process & 1.67E-04 & under & n.s. & \\
\hline GO:0006073 & $\begin{array}{l}\text { cellular glucan metabolic } \\
\text { process }\end{array}$ & $1.75 \mathrm{E}-04$ & under & n.s. & \\
\hline GO:0044042 & glucan metabolic process & $1.75 \mathrm{E}-04$ & under & n.s. & \\
\hline GO:0016773 & $\begin{array}{l}\text { phosphotransferase activity, } \\
\text { alcohol group as acceptor }\end{array}$ & $2.50 \mathrm{E}-04$ & under & n.s. & \\
\hline GO:0016310 & phosphorylation & 3.01E-04 & under & n.s. & \\
\hline
\end{tabular}

(P. purpureum) and a small number of progeny from apomictic $\mathrm{BC}_{8}$ segregating for mode of reproduction, 45 contigs showed specific amplification from PS26 and apomictic $\mathrm{BC}_{8}$ but no amplification from IA4X or sexual $\mathrm{BC}_{8}$ individuals (Figure 4, Table 2) establishing linkage of 45 contigs to the ASGR-carrier chromosome. Singlestrand conformation polymorphism analysis (SSCP) and a CAPS screen using two to four restriction enzymes was applied to the 14 primer pairs which amplified products in both PS26 and IA4X DNA. Four additional contigs could be linked to the ASGR-carrier chromosome using SSCP analysis (Table 2). The CAPS screen identified a HaeIII polymorphism for PS26_c2552, a transcript also mapped by SSCP.
The markers from the 49 ASGR-carrier chromosomelinked contigs were initially screened on a limited number of apomictic (4) and sexual (4) $\mathrm{F}_{1} \mathrm{~s}$ for mapping to the ASGR. This resulted in one contig, PS26_c9369, showing tight linkage to the ASGR as the primers amplified DNAs from only apomictic $F_{1} s$ but not sexual $\mathrm{F}_{1} \mathrm{~s}$ (Figure 5, Table 2). The remaining primer sets did not show amplification specificity in the $F_{1}$ population; both apomictic and sexual progeny amplified.

A larger $F_{1}$ population of 22 individuals (10 apomictic and 12 sexual) was used to map the PS26_c9369 and PS26_c2552 transcripts. PS26_c2552 was mapped based on the HaeIII polymorphism found in the CAPS screen between PS26 and IA4X and also seen in the $F_{1}$ 


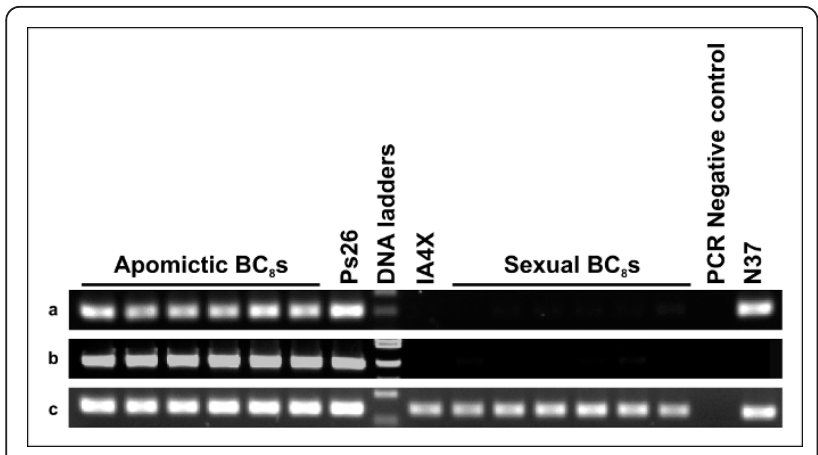

Figure 4 Examples for mapping of transcripts to the ASGRcarrier chromosome. a: amplification from PS26, N37 and apomictic $\mathrm{BC}_{8}$ but not from IA4X or sexual BC $($ PS26_c583: p1510/p1511). b: amplification from PS26 and apomictic BC ${ }_{8}$ but not from IA4X, N37 or sexual BC (PS26_c9369: p1514/p1515). C: amplification from PS26,

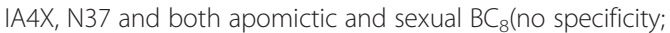
PS26_c4364: p1504/p1505). Specificity for PS26_c4364 subsequently was achieved by using a different primer pair (Table 2).

population. PS26_c2552 is unlinked to the ASGR as the CAPS polymorphism segregated 1:1 in the population but with 7 sexual and 5 apomictic individuals containing the marker. In comparison, the PS26_c9369 primers remained specific to the 10 apomictic plants and did not amplify the 12 sexual plants.

BlastX searches against NCBI databases were carried out for the $49 \mathrm{PS} 26 / \mathrm{BC}_{8}$ ASGR-carrier chromosome linked contigs and best protein hits for 18 contigs are summarized in Table 3. Because the sequences are 3' biased, a BlastN analysis against the expressed sequence tag (EST_OTHERS) database at NCBI with the remaining $31 \mathrm{PS} 26 / \mathrm{BC}_{8}$ contigs was done to find potential orthologs from other species. At an E-value cutoff of $\mathrm{e}^{-}$ ${ }^{20}, 18$ contigs had EST hits (Table 3). A BlastX was performed using these EST sequences to determine if tentative protein functions could be obtained, and the best hits are listed in Table 3. The remaining 13 (27\%) contigs did not have hits by either BlastX or BlastN; therefore, they were considered orphan genes.

In order to generate contiguous sequence that might enhance the potential for mapping of contigs in the $F_{1}$ population and to extract a longer cDNA sequence for PS26_c9369, a cDNA library containing 300,000 phage plaques was constructed from apomictic $\mathrm{BC}_{8}$ mature ovary and anther RNA since all 49 ASGR-carrier chromosome transcripts showed expression in these tissues by RT-PCR. Screening of the cDNA library with 27 ASGR-carrier chromosome transcript probes yielded hybridization signals for 24 probes. PCR screening with the ASGR-carrier chromosome-specific primers identified 16 ASGR-carrier chromosome clones and one clone for PS26_c9369. Additional sequence for these clones was generated.
The PS26_c9369 clone contained a 646 bp insert. BlastX analysis identified similarity to a hypothetical protein SORBIDRAFT_10g020450 (XP_002438482.1; evalue $6 \mathrm{e}^{-18}$ ) and Oryza sativa hypothetical protein OsJ_30933 [EAZ15525.1; e-value 4e $\mathrm{e}^{-16}$ ] over an $\sim 155 \mathrm{bp}$ region. In both sorghum and rice, the area of similarity overlapped a pfam03004: Transposase_24 domain for those proteins. The remaining PS26_c9369 clone sequence was unique. Nine primer sets were designed from nine PS26 contigs to span introns based on predicted splicing of best hits to sorghum. Five primer sets gave strong amplification of PS26 genomic DNA. These amplicons were cloned and sequenced to identify SNPs within the PS26 genomic alleles. CAPS markers could be designed for PS26_c1580 (HpyCH4IV) and PS26_c33813 (HpyCH4IV). Mapping of 4 apomictic and 4 sexual $F_{1} s$ did not show tight linkage of these contigs to the ASGR.

\section{Expression profiles of ASGR-linked expressed transcripts by RT-PCR}

RT-PCR with RNA extracted from apomictic $\mathrm{BC}_{8}$ leaf, root, anther, and ovary tissues was completed for the 49 candidate genes mapped to the ASGR-carrier chromosome. Forty-seven were expressed in all four organ types examined (Figure 6a). However, one putative MADSdomain containing transcription factor, corresponding to contig PS26_c33813, showed amplification only in anther and ovary tissues (Figure 6b) and contig PS26_c10535, a putative Lon protease, showed expression in all organs except anther.

\section{Discussion}

Transcriptional profiling has been extensively used for gene discovery in plants because the absence of introns greatly enhances the information content of the data set and eases data interpretation [41-43]. Combined with 454 high-throughput sequencing technology, transcriptome sequencing has become an approach to understand molecular events at the gene expression level on a genome-wide scale. Many successful applications of 454 sequencing technology in transcriptome sequencing and single nucleotide polymorphism (SNP) discovery have been reported [44-49] and supported our use of this technology for ovule transcriptome sequencing.

In contrast to studies aimed at identifying genes involved in apomictic reproduction through the identification of differences between apomictic and sexual genotypes, our study compared two apomictic lines for identical transcripts. We previously reported that the ASGR is sufficient to induce apomixis in sexual pearl millet [11,12]; therefore, the trait of apomixis in $\mathrm{BC}_{8}$ is conferred by the ASGR-carrier chromosome from PS26 [31]. In the present study, we have attempted to identify 
Table 2 Summary of mapping results

\begin{tabular}{|c|c|c|c|c|c|c|c|}
\hline PS26 contig name & Primers & size & PS26 & IA4X & N37 & $\begin{array}{l}\text { Transcripts mapped } \\
\text { to the ASGR-carrier } \\
\text { chromosome }\end{array}$ & $\begin{array}{l}\text { Transcripts mapped } \\
\text { as tightly linked to } \\
\text { the ASGR locus }\end{array}$ \\
\hline PS26_c9369 & $1514 / 1515$ & 274 & + & - & - & Yes & Yes \\
\hline PS26_c10331 & $1476 / 1477$ & 210 & + & - & - & Yes & $\mathrm{np}$ \\
\hline PS26_C13922 & $1486 / 1487$ & 200 & + & - & - & Yes & $\mathrm{np}$ \\
\hline PS26_c5080 & $\begin{array}{l}1506 / 1507 \\
1744 / 1745^{\text {CAPS }}\end{array}$ & $\begin{array}{l}204 \\
800\end{array}$ & $\begin{array}{l}+ \\
+\end{array}$ & $\begin{array}{l}- \\
+\end{array}$ & - & $\begin{array}{l}\text { Yes } \\
\text { Yes }\end{array}$ & $\begin{array}{l}\mathrm{np} \\
\text { No }\end{array}$ \\
\hline PS26_c2339 & $1528 / 1529$ & 213 & + & - & - & Yes & $\mathrm{np}$ \\
\hline PS26_c2785 & $1534 / 1535$ & 226 & + & - & - & Yes & $\mathrm{np}$ \\
\hline PS26_C194 & $1604 / 1605$ & 283 & + & - & - & Yes & $\mathrm{np}$ \\
\hline PS26_c2838 & $1642 / 1643$ & 103 & + & - & - & Yes & $\mathrm{np}$ \\
\hline PS26_c3609 & $1646 / 1647$ & 150 & + & - & - & Yes & $\mathrm{np}$ \\
\hline PS26_c5210 & $1652 / 1653$ & 157 & + & - & - & Yes & $\mathrm{np}$ \\
\hline PS26_c6744 & $1658 / 1659$ & 202 & + & - & - & Yes & $\mathrm{np}$ \\
\hline PS26_c5851 & $1654 / 1655$ & 179 & + & - & - & Yes & $\mathrm{np}$ \\
\hline PS26_C1406 & $1583 / 1681$ & 250 & + & - & - & Yes & $\mathrm{np}$ \\
\hline PS26_c28392 & $1704 / 1705$ & 181 & + & - & - & Yes & $\mathrm{np}$ \\
\hline \multirow[t]{2}{*}{ PS26_c4364 } & $1505 / 1716$ & 150 & + & - & - & Yes & $\mathrm{np}$ \\
\hline & $1504 / 1505$ & 140 & + & + & + & $\mathrm{np}$ & $\mathrm{np}$ \\
\hline PS26_C11544 & $1478 / 1479$ & 165 & + & - & + & Yes & $\mathrm{np}$ \\
\hline PS26_C13157 & $1480 / 1481$ & 161 & + & - & + & Yes & $\mathrm{np}$ \\
\hline PS26_C13655 & $1482 / 1483$ & 214 & + & - & + & Yes & $\mathrm{np}$ \\
\hline PS26_C1372 & $1484 / 1485$ & 215 & + & - & + & Yes & $\mathrm{np}$ \\
\hline PS26_c2448 & $1492 / 1493$ & 189 & + & - & + & Yes & $\mathrm{np}$ \\
\hline PS26_c30691 & 1498/1499 & 206 & + & - & + & Yes & $\mathrm{np}$ \\
\hline PS26_c3546 & $1500 / 1501$ & 245 & + & - & + & Yes & $\mathrm{np}$ \\
\hline PS26_c583 & $1510 / 1511$ & 212 & + & - & + & Yes & $\mathrm{np}$ \\
\hline PS26_c8165 & $1512 / 1513$ & 150 & + & - & + & Yes & $\mathrm{np}$ \\
\hline PS26_C1279 & $1530 / 1531$ & 228 & + & - & + & Yes & $\mathrm{np}$ \\
\hline PS26_c7587 & $1532 / 1533$ & 172 & + & - & + & Yes & $\mathrm{np}$ \\
\hline PS26_C17388 & 1538/1539 & 163 & + & - & + & Yes & $\mathrm{np}$ \\
\hline PS26_c3455 & $1540 / 1541$ & 102 & + & - & + & Yes & $\mathrm{np}$ \\
\hline PS26_C1312 & $1542 / 1543$ & 143 & + & - & + & Yes & $\mathrm{np}$ \\
\hline PS26_c338 & $1548 / 1549$ & 120 & + & - & + & Yes & $\mathrm{np}$ \\
\hline PS26_c33813 & $\begin{array}{l}1565 / 1566 \\
1724 / 1725^{\text {CAPS }}\end{array}$ & $\begin{array}{l}140 \\
900\end{array}$ & $\begin{array}{l}+ \\
+\end{array}$ & $\begin{array}{l}- \\
+\end{array}$ & $\stackrel{+}{N / A}$ & $\begin{array}{l}\text { Yes } \\
\text { Yes }\end{array}$ & $\begin{array}{l}\mathrm{np} \\
\mathrm{No}\end{array}$ \\
\hline PS26_c1422 & $1567 / 1568$ & 120 & + & - & + & Yes & $\mathrm{np}$ \\
\hline PS26_c6131 & $1571 / 1572$ & 179 & + & - & + & Yes & $\mathrm{np}$ \\
\hline PS26_c2388 & $1575 / 1576$ & 128 & + & - & + & Yes & $\mathrm{np}$ \\
\hline PS26_c32589 & $1581 / 1582$ & 216 & + & - & + & Yes & $\mathrm{np}$ \\
\hline PS26_C10535 & $1630 / 1631$ & 148 & + & - & + & Yes & $\mathrm{np}$ \\
\hline PS26_c2807 & $1640 / 1641$ & 164 & + & - & + & Yes & $\mathrm{np}$ \\
\hline PS26_c9776 & $1664 / 1665$ & 170 & + & - & + & Yes & $\mathrm{np}$ \\
\hline PS26_c6373 & $1656 / 1657$ & 178 & + & - & + & Yes & $\mathrm{np}$ \\
\hline PS26_c1878 & $1690 / 1691$ & 157 & + & - & + & Yes & $\mathrm{np}$ \\
\hline PS26_C19109 & $1692 / 1693$ & 163 & + & - & + & Yes & $\mathrm{np}$ \\
\hline PS26_c22381 & $1696 / 1697$ & 246 & + & - & + & Yes & $\mathrm{np}$ \\
\hline PS26_c4150 & $1650 / 1715$ & 450 & + & - & + & Yes & $\mathrm{np}$ \\
\hline PS26_C704 & 1708/1709 & 155 & + & - & + & Yes & $\mathrm{np}$ \\
\hline PS26_c3993 & $1502 / 1713$ & 800 & + & - & + & Yes & $\mathrm{np}$ \\
\hline PS26_c30198 & $1496 / 1497^{\text {SSCP }}$ & 210 & + & + & + & Yes & $\mathrm{np}$ \\
\hline PS26_c1472 & $1573 / 1574^{\mathrm{SSCP}}$ & 185 & + & + & + & Yes & $\mathrm{np}$ \\
\hline
\end{tabular}


Table 2 Summary of mapping results (Continued)

\begin{tabular}{|c|c|c|c|c|c|c|c|}
\hline PS26_c2552 & $1670 / 1671^{\text {SSCP/CAPS }}$ & 243 & + & + & + & Yes & No \\
\hline PS26_c14318 & $1666 / 1667^{\text {SSCP }}$ & 175 & + & + & + & Yes & np \\
\hline PS26_c6192 & $1720 / 1721$ & 140 & + & + & + & $\mathrm{np}$ & $n p$ \\
\hline PS26_c20942 & $1488 / 1489$ & 125 & + & + & + & $\mathrm{np}$ & np \\
\hline PS26_c24301 & $1490 / 1491$ & 120 & + & + & + & $\mathrm{np}$ & $\mathrm{np}$ \\
\hline PS26_c25664 & $1494 / 1495$ & 193 & + & + & + & $\mathrm{np}$ & $\mathrm{np}$ \\
\hline PS26_c5781 & $1508 / 1509$ & 156 & + & + & + & $\mathrm{np}$ & np \\
\hline PS26_c2405 & $1577 / 1578$ & 180 & + & + & + & $\mathrm{np}$ & $\mathrm{np}$ \\
\hline PS26_C15085 & $1579 / 1580$ & 120 & + & + & + & $\mathrm{np}$ & $\mathrm{np}$ \\
\hline PS26_C1580 & $1628 / 1629$ & 237 & + & + & + & $\mathrm{np}$ & $\mathrm{np}$ \\
\hline PS26_c18163 & $1632 / 1633$ & 169 & + & + & + & $\mathrm{np}$ & np \\
\hline PS26_c3656 & $1648 / 1649$ & 152 & + & + & + & $\mathrm{np}$ & $n p$ \\
\hline PS26_c21597 & $1668 / 1669$ & 150 & + & + & + & $\mathrm{np}$ & $n p$ \\
\hline PS26_C8378 & $1662 / 1663$ & 199 & pf & pf & pf & N/A & N/A \\
\hline
\end{tabular}

The one contig mapped to the ASGR is shown in bold. +: positive amplification; -: no amplification; pf: primer failure; np: no polymorphism available for mapping; N/A: not assayed. Primer sequences and annealing temperatures can be found in Additional file 3 - Table S1.

candidate genes regulating the first step of apomixis, aposporous initial development, by transcriptome analysis of ovules from both PS26 and $\mathrm{BC}_{8}$. The ovules were collected at the stage of aposporous initial development, which ranged from no apparent apospory initials ( 70\%) to distinct aposporous initials observed ( $30 \%)$. By pooling ovules over this range of development our objective was to minimize the chance of missing genes involved in the pathway of apomixis initiation since we would predict transcription prior to, and perhaps beyond, apospory initial formation.

The two ovule transcriptomes generated had an average read length of $\sim 150 \mathrm{bp}$, shorter than the average read length of 200-300 bases for the 454 GS FLX sequencer. The shorter than expected reads could have been due to a combination of factors in preparing the samples for sequencing such as the T7-based antisense RNA amplification method, the conversion of antisense

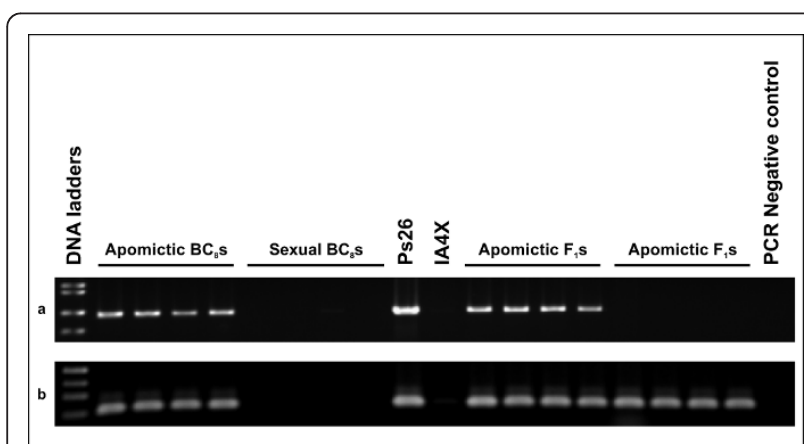

Figure 5 Examples for mapping of transcripts to the ASGR. a: amplification of apomictic F1s but not sexual F1s (PS26_c9369: p1514/p1515). b: amplification of both apomictic F1s and sexual F1s (PS26_c5080: p1506/p1507).
RNA to cDNA, or during the shearing process of the cDNA to prepare the sequencing library. Another possible factor is the species itself. It has been shown that the average read length can vary among different organisms due to differences in AT/GC content [32].

Even with short reads and using stringent comparison conditions to decrease the number of false positive joins between highly similar but not identical transcripts from the two species, 61 putative ASGR-carrier chromosome candidate expressed genes were identified in silico, of which 49 have confirmed linkage to the ASGR-carrier chromosome. The 3' bias of the T7 amplified transcripts helped in the design of primers to discriminate between $P$. squamulatum and the $\mathrm{BC}_{8}$ pearl millet genome containing one $P$. squamulatum chromosome. Our sequencing strategy helped remove, at least to a chromosomal level, the difficulties associated with candidate gene identification by comparative gene expression analysis in apomictic and sexual systems which lack, due to the apomictic process, an ability to generate isogenic lines that vary only in their mode of reproduction. Primer specificity for 48 transcripts was not seen when we attempted to map SCARs to the ASGR using a $F_{1}$ population containing many $P$. squamulatum chromosomes. The additional sequence generated by the phage cDNA clones allowed mapping of two more transcripts in the $\mathrm{F}_{1}$ population. Greater sequence length would be advantageous for mapping of the ASGR-carrier chromosome transcripts to the ASGR locus.

The use of the gene ontology software Blast2Go allowed comparison of both the PS26 and $\mathrm{BC}_{8}$ libraries and the PS26_EST_OTHERS and $\mathrm{BC}_{8}$ EST_OTHERS libraries created by using the most significant EST_OTHERS BlastN result as a surrogate for our sequences. The PS26 and $\mathrm{BC}_{8}$ transcriptomes were almost identical 
Table 3 Potential function of transcripts mapping to the ASGR-carrier chromosome based on BlastX or BlastN.

\begin{tabular}{|c|c|c|c|c|c|}
\hline $\begin{array}{l}\text { Ps26 } \\
\text { Contig }\end{array}$ & $\begin{array}{l}\mathrm{BC}_{8} \\
\text { Contig }\end{array}$ & $\begin{array}{l}\text { Overlap } \\
\text { length } \\
\text { (bp) }\end{array}$ & BlastX & BlastN (E-Value) to EST_OTHERS & $\begin{array}{l}\text { BlastX of EST hit in BlastN } \\
\text { column }\end{array}$ \\
\hline $\begin{array}{l}\text { Ps26- } \\
\text { C10331 }\end{array}$ & $\begin{array}{l}\mathrm{BC}_{8-} \\
\mathrm{C} 7991\end{array}$ & 241 & no hit & $\begin{array}{l}\text { RCRST0_005870 Foxtail millet EC612643.1 } \\
\text { Gl:149362118 (3e-55) }\end{array}$ & no hit \\
\hline $\begin{array}{l}\text { Ps26 } \\
\text { C11544 }\end{array}$ & $\begin{array}{l}\mathrm{BC}_{8-} \\
\mathrm{C} 10325\end{array}$ & 228 & no hit & no hit & \\
\hline $\begin{array}{l}\text { Ps26 } \\
\text { C13157 }\end{array}$ & $\begin{array}{l}\mathrm{BC}_{8-} \\
\mathrm{C} 5112\end{array}$ & 227 & no hit & no hit & \\
\hline $\begin{array}{l}\text { Ps26_ } \\
\text { C13655 }\end{array}$ & $\begin{array}{l}\mathrm{BC}_{8-} \\
\mathrm{C} 24571\end{array}$ & 192 & no hit & $\begin{array}{l}\text { pPAP_06_E02 Apomictic pistil BM084376.1 } \\
\text { GI:27532285 (8e-24) }\end{array}$ & $\begin{array}{l}\text { putative } 265 \text { proteasome non- } \\
\text { ATPase regulatory subunit } 3 \\
\text { ACG34075.1 Gl:195624490 }\end{array}$ \\
\hline $\begin{array}{l}\text { Ps26- } \\
\text { c1372 }\end{array}$ & $\begin{array}{l}\mathrm{BC}_{8-} \\
\mathrm{C} 12789\end{array}$ & 326 & no hit & $\begin{array}{l}\text { CCGC4364.g1 CCGC Panicum virgatum early } \\
\text { floral buds + reproductive tissue FL750787.1 } \\
\text { Gl:198007657 (e-174) }\end{array}$ & $\begin{array}{l}\text { NADH-ubiquinone oxidoreductase } \\
51 \mathrm{kDa} \text { subunit NP_001148767.1 } \\
\text { Gl:226532265 }\end{array}$ \\
\hline $\begin{array}{l}\text { Ps26- } \\
\text { C13922 }\end{array}$ & $\begin{array}{l}\mathrm{BC}_{8-} \\
\mathrm{C} 12833\end{array}$ & 212 & no hit & no hit & \\
\hline $\begin{array}{l}\text { Ps26 } \\
\text { c2448 }\end{array}$ & $\begin{array}{l}\mathrm{BC}_{8-} \\
\mathrm{C} 12858\end{array}$ & 225 & no hit & $\begin{array}{l}\text { pPAP_10_F04 Apomictic pistil FL813942.1 } \\
\text { Gl:198086024 (2e-57) }\end{array}$ & $\begin{array}{l}\text { ankyrin protein kinase-like } \\
\text { NP_001152470.1 Gl:226495939 }\end{array}$ \\
\hline $\begin{array}{l}\text { Ps26_ } \\
\text { c30691 }\end{array}$ & $\begin{array}{l}\mathrm{BC}_{8-} \\
\mathrm{C} 10294\end{array}$ & 206 & no hit & no hit & \\
\hline $\begin{array}{l}\text { Ps26 } \\
\text { c3546 }\end{array}$ & $\begin{array}{l}\mathrm{BC}_{8-} \\
\mathrm{C} 8622\end{array}$ & 295 & no hit & no hit & \\
\hline $\begin{array}{l}\text { Ps26 } \\
\text { C5080 }\end{array}$ & $\begin{array}{l}\mathrm{BC}_{8-} \\
\mathrm{C} 12542\end{array}$ & 212 & $\begin{array}{l}\text { hypothetical protein Os」_24918 } \\
\text { EEE67490.1 Gl:222637358 }\end{array}$ & & \\
\hline $\begin{array}{l}\text { Ps26_ } \\
\text { C583 }\end{array}$ & $\begin{array}{l}\mathrm{BC}_{8-} \\
\mathrm{C} 6141\end{array}$ & 223 & no hit & $\begin{array}{l}\text { 6X_JF-rd_A11 pAPO Cenchrus ciliaris } \\
\text { EB652936.1 Gl:164107582 (6e-127) }\end{array}$ & $\begin{array}{l}\text { SRC2 protein kinase C } \\
\text {-phospholipids ACG40316.1 } \\
\text { Gl:195641696] }\end{array}$ \\
\hline $\begin{array}{l}\text { Ps26 } \\
\text { c8165 }\end{array}$ & $\begin{array}{l}\mathrm{BC}_{8-} \\
\mathrm{C} 5964\end{array}$ & 185 & no hit & $\begin{array}{l}\text { 84Z_JF_G03 pAPO Cenchrus ciliaris EB661430.1 } \\
\text { Gl:164123871 (7e-70) }\end{array}$ & $\begin{array}{l}\text { TPA: AT-hook motif nuclear } \\
\text { localized protein } 2 \text { FAA00302.1 } \\
\text { Gl:119657406 }\end{array}$ \\
\hline $\begin{array}{l}\text { Ps26 } \\
\text { c9369 }\end{array}$ & $\begin{array}{l}\mathrm{BC}_{8-} \\
\mathrm{C} 3452\end{array}$ & 190 & $\begin{array}{l}\text { hypothetical protein OsJ_30933 } \\
\text { EAZ15525.1 Gl:1255744241 }\end{array}$ & & \\
\hline $\begin{array}{l}\text { Ps26 } \\
\text { c2339 }\end{array}$ & $\begin{array}{l}\mathrm{BC}_{8-} \\
\mathrm{C} 7917\end{array}$ & 264 & no hit & $\begin{array}{l}\text { CCGG12847.g1 CCGG Panicum virgatum late } \\
\text { flowering buds FL812358.1 Gl:198084376 (e- } \\
\text { 23) }\end{array}$ & $\begin{array}{l}\text { ESP4 (ENHANCED SILENCING } \\
\text { PHENOTYPE 4) NP_195760.1 } \\
\text { Gl:15240970 }\end{array}$ \\
\hline $\begin{array}{l}\text { Ps26 } \\
\text { C1279 }\end{array}$ & $\begin{array}{l}\mathrm{BC}_{8-} \\
\mathrm{C} 8634\end{array}$ & 243 & $\begin{array}{l}\text { ENT domain containing protein } \\
\text { ACG36577.1 Gl:195629872 }\end{array}$ & & \\
\hline $\begin{array}{l}\text { Ps26 } \\
\text { C7587 }\end{array}$ & $\begin{array}{l}\mathrm{BC}_{8-} \\
\mathrm{C} 11918\end{array}$ & 202 & $\begin{array}{l}\text { ATPNG1 (Arabidopsis Thaliana } \\
\text { PEPTIDE-N-GLYCANASE 1) } \\
\text { NP_199768.1 Gl:15240508 }\end{array}$ & & \\
\hline $\begin{array}{l}\text { Ps26 } \\
\text { c2785 }\end{array}$ & $\begin{array}{l}\mathrm{BC}_{8} \\
\mathrm{C} 8847\end{array}$ & 273 & $\begin{array}{l}\text { ubiquitin-conjugating enzyme E2 } \\
\text { N NP_001148361.1 Gl:226491078 }\end{array}$ & & \\
\hline $\begin{array}{l}\text { Ps26- } \\
\text { c194 }\end{array}$ & $\begin{array}{l}\mathrm{BC}_{8-} \\
\mathrm{C} 2920\end{array}$ & 304 & no hit & no hit & \\
\hline $\begin{array}{l}\text { Ps26- } \\
\text { C17388 }\end{array}$ & $\begin{array}{l}\mathrm{BC}_{8-} \\
\mathrm{C} 6454\end{array}$ & 208 & $\begin{array}{l}\text { histone } 4 \text { BAG68513.1 } \\
\text { Gl:195972757 }\end{array}$ & & \\
\hline $\begin{array}{l}\text { Ps26 } \\
\text { c3455 }\end{array}$ & $\begin{array}{l}\mathrm{BC}_{8-} \\
\mathrm{C} 8607\end{array}$ & 193 & no hit & $\begin{array}{l}\text { 26X_JF_C01 pAPO Cenchrus ciliaris EB655151.1 } \\
\text { Gl:164198597 (e-102) }\end{array}$ & $\begin{array}{l}\text { putative condensing } \\
\text { XP_002529162.1 Gl:255576542 }\end{array}$ \\
\hline $\begin{array}{ll}\text { Ps26- } \\
\text { C1312 }\end{array}$ & $\begin{array}{l}\mathrm{BC}_{8-} \\
\mathrm{C} 3757\end{array}$ & 313 & no hit & $\begin{array}{l}\text { 25X_JF_D10 pAPO Cenchrus ciliaris EB656417.1 } \\
\text { Gl:164027660 (2e-47) }\end{array}$ & $\begin{array}{l}\text { protein phosphatase 2A regulatory } \\
\text { subunit A AAM94368.1 Gl:22296816 }\end{array}$ \\
\hline $\begin{array}{l}\text { Ps26 } \\
\text { c338 }\end{array}$ & $\begin{array}{l}\mathrm{BC}_{8-} \\
\mathrm{C} 3527\end{array}$ & 419 & $\begin{array}{l}\text { universal stress protein (USP) } \\
\text { family protein NP_001159067.1 } \\
\text { Gl:259490110 }\end{array}$ & & \\
\hline $\begin{array}{l}\text { Ps26- } \\
\text { c33813 }\end{array}$ & $\begin{array}{l}\mathrm{BC}_{8-} \\
\mathrm{C} 2708\end{array}$ & 229 & $\begin{array}{l}\text { putative MADS-domain } \\
\text { transcription factor } \\
\text { CAA70485.1 Gl:3851333 }\end{array}$ & & \\
\hline
\end{tabular}


Table 3 Potential function of transcripts mapping to the ASGR-carrier chromosome based on BlastX or BlastN. (Continued)

\begin{tabular}{|c|c|c|c|c|c|}
\hline $\begin{array}{l}\text { Ps26- } \\
\text { c1422 }\end{array}$ & $\begin{array}{l}\mathrm{BC}_{8-} \\
\mathrm{C} 3852 \\
\end{array}$ & 245 & no hit & no hit & \\
\hline $\begin{array}{l}\text { Ps26 } \\
\text { c6131 }\end{array}$ & $\begin{array}{l}\mathrm{BC}_{8-} \\
\mathrm{C} 8955\end{array}$ & 224 & no hit & $\begin{array}{l}\text { CCHY9952.g1 CCHY Panicum virgatum callus } \\
\text { FL987585.1 Gl:198319427 (e-49) }\end{array}$ & $\begin{array}{l}\text { putative calcium-dependent } \\
\text { protein kinase ACG46220.1 } \\
\text { Gl:195653505 }\end{array}$ \\
\hline $\begin{array}{l}\text { Ps26- } \\
\text { c2388 }\end{array}$ & $\begin{array}{l}\mathrm{BC}_{8-} \\
\mathrm{C} 2949\end{array}$ & 201 & no hit & $\begin{array}{l}\text { 6W6III_JF_H03 pAPO Cenchrus ciliaris } \\
\text { EB662068.1 Gl:164227478 (3e-48) }\end{array}$ & $\begin{array}{l}\text { polygalacturonase inhibitor } 1 \\
\text { precursor ACG36448.1 Gl:195629614 }\end{array}$ \\
\hline $\begin{array}{l}\text { Ps26- } \\
\text { c32589 }\end{array}$ & $\begin{array}{l}\mathrm{BC}_{8-} \\
\mathrm{C} 3672\end{array}$ & 229 & no hit & $\begin{array}{l}\text { 71Z_JF_B09 pAPO Cenchrus ciliaris EB654350.1 } \\
\text { Gl:163993222 (5e-93) }\end{array}$ & $\begin{array}{l}\text { putative microtubule-associated } \\
\text { protein CAD23144.1 Gl:37776903 }\end{array}$ \\
\hline $\begin{array}{l}\text { Ps26 } \\
\text { C10535 }\end{array}$ & $\begin{array}{l}\mathrm{BC}_{8-} \\
\mathrm{C} 22186\end{array}$ & 182 & no hit & no hit & \\
\hline $\begin{array}{l}\text { Ps26 } \\
\text { c2807 }\end{array}$ & $\begin{array}{l}\mathrm{BC}_{8-} \\
\mathrm{C} 12602\end{array}$ & 241 & no hit & $\begin{array}{l}\text { 5X_JF_A06 pAPO Cenchrus ciliaris EB652848.1 } \\
\text { Gl:164180053 (6e-116) }\end{array}$ & $\begin{array}{l}\text { Phosphoglucomutase/ } \\
\text { phosphomannomutase C terminal } \\
\text { ABN08987.1 Gl:124361015 }\end{array}$ \\
\hline $\begin{array}{l}\text { Ps26- } \\
\text { c2838 } \\
\end{array}$ & $\begin{array}{l}\mathrm{BC}_{8-} \\
\mathrm{C} 3538 \\
\end{array}$ & 183 & no hit & no hit & \\
\hline $\begin{array}{l}\text { Ps26 } \\
\text { c3609 }\end{array}$ & $\begin{array}{l}\mathrm{BC}_{8-} \\
\mathrm{C} 10814\end{array}$ & 245 & no hit & no hit & \\
\hline $\begin{array}{l}\text { Ps26 } \\
\text { C5210 }\end{array}$ & $\begin{array}{l}\mathrm{BC}_{8-} \\
\mathrm{C} 5192\end{array}$ & 273 & $\begin{array}{l}\text { hypothetical protein OsJ_25077 } \\
\text { EEE67565.1 Gl:222637433 }\end{array}$ & & \\
\hline $\begin{array}{l}\text { Ps26- } \\
\text { c6744 }\end{array}$ & $\begin{array}{l}\mathrm{BC}_{8} \\
\mathrm{C} 292\end{array}$ & 257 & $\begin{array}{l}\text { ADP-ribosylation factor } \\
\text { BAB90396.1 Gl:20161472 }\end{array}$ & & \\
\hline $\begin{array}{l}\text { Ps26 } \\
\text { c9776 }\end{array}$ & $\begin{array}{l}\mathrm{BC}_{8-} \\
\mathrm{C} 4965\end{array}$ & 258 & no hit & $\begin{array}{l}\text { MK_7_78 Pennisetum glaucum seedlings } \\
\text { CD726437.1 Gl:32277284 (2e-46) }\end{array}$ & $\begin{array}{l}\text { hypothetical protein } \\
\text { SORBIDRAFT_07g010440 } \\
\text { XP_002444160.1 Gl:242078783 }\end{array}$ \\
\hline $\begin{array}{l}\text { Ps26- } \\
\text { c5851 }\end{array}$ & $\begin{array}{l}\mathrm{BC}_{8-} \\
\mathrm{C} 5854\end{array}$ & 192 & no hit & no hit & \\
\hline $\begin{array}{l}\text { Ps26 } \\
\text { c6373 }\end{array}$ & $\begin{array}{l}\mathrm{BC}_{8-} \\
\mathrm{c} 6664\end{array}$ & 235 & no hit & $\begin{array}{l}\text { 1475276 CERES-197 Zea mays FL451677.1 } \\
\text { Gl:211043870 (2e-41) }\end{array}$ & $\begin{array}{l}\text { hypothetical protein LOC100276553 } \\
\text { NP_001143786.1 Gl:226505008 }\end{array}$ \\
\hline $\begin{array}{l}\text { Ps26- } \\
\text { c30198 }\end{array}$ & $\begin{array}{l}\mathrm{BC}_{8-} \\
\mathrm{C} 9466\end{array}$ & 220 & $\begin{array}{l}\text { centromere/microtubule binding } \\
\text { protein cbf5, putative } \\
\text { XP_002523427.1 Gl:255564866 }\end{array}$ & & \\
\hline $\begin{array}{l}\text { Ps26- } \\
\text { c3993 }\end{array}$ & $\begin{array}{l}\mathrm{BC}_{8-} \\
\mathrm{C} 16185\end{array}$ & 246 & $\begin{array}{l}\text { fk506-binding protein, putative } \\
\text { XP_002534360.1 Gl:255587693 }\end{array}$ & & \\
\hline $\begin{array}{l}\text { Ps26- } \\
\text { c4364 }\end{array}$ & $\begin{array}{l}\mathrm{BC}_{8-} \\
\mathrm{C} 15332\end{array}$ & 181 & no hit & $\begin{array}{l}\text { CCHZ9541.g1 CCHZ Panicum virgatum } \\
\text { GD021384.1 Gl:198352214 (5e-31) }\end{array}$ & $\begin{array}{l}\text { helix-loop-helix-like protein } \\
\text { AAO72577.1 Gl:29367409 }\end{array}$ \\
\hline $\begin{array}{l}\text { Ps26- } \\
\text { C1472 }\end{array}$ & $\begin{array}{l}\mathrm{BC}_{8} 8- \\
\mathrm{C} 3819 \\
\end{array}$ & 330 & $\begin{array}{l}\text { small zinc finger-like protein } \\
\text { AAD40002.1 Gl:5107180 }\end{array}$ & & \\
\hline $\begin{array}{l}\text { Ps26 } \\
\text { c1406 }\end{array}$ & $\begin{array}{l}\mathrm{BC}_{8-} \\
\mathrm{c} 4551\end{array}$ & 221 & $\begin{array}{l}\text { putative anther ethylene- } \\
\text { upregulated protein ER1 } \\
\text { BAC79907.1 Gl:33146619 }\end{array}$ & & \\
\hline $\begin{array}{l}\text { Ps26- } \\
\text { c1878 }\end{array}$ & $\begin{array}{l}\mathrm{BC}_{8-} \\
\mathrm{C} 7425\end{array}$ & 242 & no hit & $\begin{array}{l}\text { CCGI4193.g1 CCGI Panicum virgatum } \\
\text { FL856163.1 Gl:198128193(3e-69) }\end{array}$ & $\begin{array}{l}\text { hypothetical protein } \\
\text { SORBIDRAFT_02g036200 } \\
\text { XP_002460850.1 Gl:242045958 }\end{array}$ \\
\hline $\begin{array}{l}\text { Ps26- } \\
\text { C19109 }\end{array}$ & $\begin{array}{l}\mathrm{BC}_{8-} \\
\mathrm{C} 9186\end{array}$ & 205 & no hit & no hit & \\
\hline $\begin{array}{l}\text { Ps26- } \\
\text { c22381 }\end{array}$ & $\begin{array}{l}\mathrm{BC}_{8} \\
\mathrm{C} 54 \overline{7}\end{array}$ & 185 & no hit & $\begin{array}{l}\text { 2X61II_JF-rd_A11 pAPO Cenchrus ciliaris } \\
\text { EB652659.1 Gl:164076750 (7e-58) }\end{array}$ & $\begin{array}{l}\text { APx2 - Cytosolic Ascorbate } \\
\text { Peroxidase ACG41151.1 } \\
\text { Gl:195643366 }\end{array}$ \\
\hline $\begin{array}{l}\text { Ps26_ } \\
\text { c28392 }\end{array}$ & $\begin{array}{l}\mathrm{BC}_{8-} \\
\mathrm{C} 12100\end{array}$ & 230 & no hit & no hits & \\
\hline $\begin{array}{l}\text { Ps } 26 \\
\text { c4150 }\end{array}$ & $\begin{array}{l}\mathrm{BC}_{8-} \\
\mathrm{C} 3261\end{array}$ & 276 & $\begin{array}{l}\text { rRNA-processing protein EBP2, } \\
\text { putative XP_002526440.1 } \\
\text { Gl:255570978 }\end{array}$ & & \\
\hline $\begin{array}{l}\text { Ps26- } \\
\text { c704 }\end{array}$ & $\begin{array}{l}\mathrm{BC}_{8-} \\
\mathrm{C} 1322\end{array}$ & 368 & $\begin{array}{l}\text { 26S protease regulatory subunit, } \\
\text { Putative XP_002526219.1 } \\
\text { Gl:255570523 }\end{array}$ & & \\
\hline
\end{tabular}


Table 3 Potential function of transcripts mapping to the ASGR-carrier chromosome based on BlastX or BlastN. (Continued)

\begin{tabular}{|c|c|c|c|}
\hline $\begin{array}{l}\text { Ps26 } \\
\text { c2552 }\end{array}$ & $\begin{array}{l}\mathrm{BC}_{8-} \\
\mathrm{C} 1808\end{array}$ & 384 & $\begin{array}{l}\text { 40S ribosomal protein S6 } \\
\text { ACG31980.1 Gl:195620300 }\end{array}$ \\
\hline $\begin{array}{l}\text { Ps26 } \\
\text { C14318 }\end{array}$ & $\begin{array}{l}\mathrm{BC}_{8} \\
\mathrm{C} 14583\end{array}$ & 366 & $\begin{array}{l}\text { triose phosphate/phosphate } \\
\text { translocator ACG33816.1 } \\
\text { Gl:195623972 }\end{array}$ \\
\hline
\end{tabular}

Potential functions of the inter-genotype contigs sharing $100 \%$ identity between PS26 and BC ${ }_{8}$ ovule transcripts which could be mapped to the ASGR-carrier chromosome based on the best hit of the contigs to protein (BlastX) or nucleotide (BlastN) sequences in NCBI databases.

on a level 3 biological process comparison. While many biological GO terms showed expression level differences when comparing the PS26 and $\mathrm{BC}_{8}$ libraries, all but seven became non-significant when the PS26_EST_OTHERS and $\mathrm{BC}_{8}$ EST_OTHERS libraries were compared. Six of the transcriptional differences noted belong to genes involved in either ribosomal or translational functions. This difference may be caused by ploidy level difference of PS26 (an octoploid) and $\mathrm{BC}_{8}$ (a tetraploid). MIRA assembly will separate alleles of genes into different contigs. More PS26 allelic transcripts for genes involved in either ribosomal or translational functions may be expressed in PS26 than in $\mathrm{BC}_{8}$ thus leading to a higher transcript difference between the libraries.

Expression analysis of the ASGR-carrier chromosome linked genes in $\mathrm{BC}_{8}$ tissue was used to identify transcripts specific to reproductive tissue. All but two ASGR-carrier chromosome transcripts showed constitutive expression in both vegetative and reproductive tissues. The one reproduction-specific transcript (the MADS box gene) did not map to the ASGR. The transcript which could be mapped to the ASGR shows similarity to "hypothetical" proteins in both sorghum and rice containing a Transposase_24 domain. Previous sequencing of BAC clones linked to the ASGR have

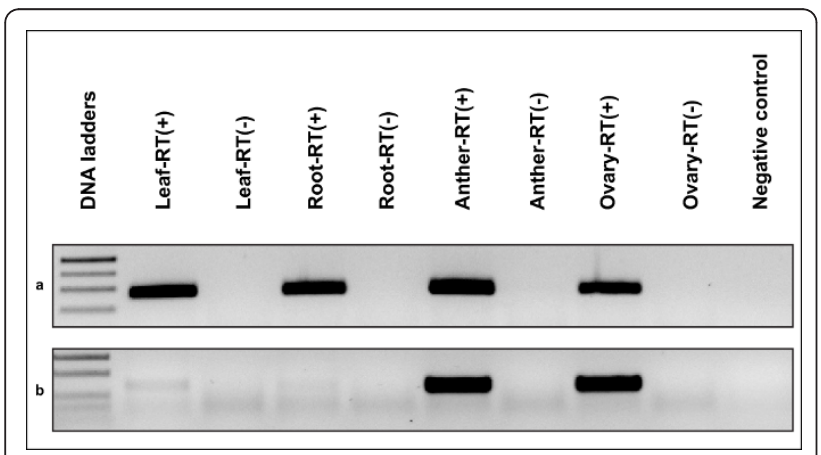

Figure 6 Examples of expression patterns for ASGR-carrier chromosome linked sequences. a: most genes showed expression in all four organs tested (Ps26_c194: p1604/p1605). b: one gene was expressed in only ovary and anther (PS26_c33813: p1565/p1566). RT(+): RT with reverse transcriptase; RT(-): RT without reverse transcriptase as DNA contamination control. shown a large number of both Type I and Type II transposons at the locus [50,13]; therefore, it is not surprising that we identified an ASGR-linked transposon transcript in our study.

\section{Conclusions}

Our data show that the combination of selecting specific reproductive tissues and sequencing with 454 highthroughput sequencing technology is a promising approach for identification of genes involved in different developmental events and that a need for longer transcript contigs will be a requirement to allow for easier mapping of these transcripts. Given the rapid advancements in next-generation sequencing technologies that enable very deep sequence coverage and paired-end reads, it is likely that the fine tissue dissection requiring RNA amplification of starting materials now could be eliminated to favor longer transcript assemblies.

\section{Methods}

\section{Plant materials}

Pennisetum squamulatum (PS26; PI 319196, 2n = 56) and backcross line $8\left(\mathrm{BC}_{8}\right)$-line 58were used for ovule collection. Compared with the $\mathrm{BC}_{7}$ line which was used in previous studies [12], the $\mathrm{BC}_{8}$-line 58 contains only one alien chromosome from PS26, the ASGR-carrier chromosome [31]. P. glaucum (IA4X), P. purpureum (N37), 4 apomictic and 4 sexual plants from $\mathrm{BC}_{8}$-line 58 $\left(\mathrm{BC}_{8}\right.$ is facultative thus it produces $\sim 18 \%$ sexually derived offspring were used for assigning the candidate transcript fragments to the ASGR-carrier chromosome. Twenty-two individuals from a segregating $F_{1}$ population between $P$. squamulatum and $P$. glaucum were used for mapping the transcript fragments to the ASGR.

\section{RNA isolation}

Young florets were dissected from small inflorescence sections whose anthers were at stages between premeiosis and prophase, as determined by acetocarmine staining of anther squashes. One group of florets was stored in RNALater ${ }^{\circledR}$ solution (Ambion, Austin, TX, USA) at $4^{\circ} \mathrm{C}$ while the other group was processed for ovary clearing by methyl salicylate [51] to screen for the ovary developmental stage. Ovules from thirty cleared florets 
were examined for each group. If the cleared sample showed AIs in less than $30 \%$ of the ovaries and the remaining ovaries were at an earlier developmental stage, then florets stored in RNALater ${ }^{\mathbb{R}}$ solution from the same section of inflorescence were used for ovule dissection. About 40 ovules per sample were collected and total RNA was extracted from the ovules with RNAqueous ${ }^{\mathbb{B}}$-Micro Kit (Ambion). RNA integrity and quantity were analyzed with an Agilent 2100 Bioanalyser (Santa Clara, CA) at the Interdisciplinary Center for Biotechnology Research (ICBR) of the University of Florida.

\section{RNA amplification and ds-cDNA synthesis for Roche 454 sequencing}

With total RNA as starting material, mRNA was amplified by T7-based in vitro transcription following the manual of TargetAmp ${ }^{\mathrm{TM}} 2$-Round aRNA Amplification Kit 2.0 (Epicentre, Madison, WI). Size range and quantity of the amplified mRNA were measured by both gel electrophoresis and Agilent 2100 Bioanalyser analysis. For each sample, an equal amount of amplified mRNA from the three biological replicates was pooled for dscDNA synthesis following the protocol developed by the Schnable lab [52]. Size-range and quantity of ds-cDNA were also analyzed by both gel electrophoresis and using the Agilent 2100 Bioanalyser before submitting the samples for sequencing.

\section{4 sequencing and processing}

About $6 \mu \mathrm{g}$ of ds-cDNA from both PS26 and $\mathrm{BC}_{8}$ was submitted to the Genome Sequencing Center at Washington University for 454-FLX sequencing. Samples of cDNA were subjected to mechanical shearing (nebulization), size selected, and blunt-end fragments were ligated to short adaptors, which provided primer target sites for both amplification and sequencing. Sequencing files (Accession \#SRA030528) were submitted to the Sequence Read Archive at NCBI http:// trace.ncbi.nlm.nih.gov/Traces/sra/sra.cgi?view=studies. The Multifunctional Inertial Reference Assembly (MIRA) program [38] was used to process and assemble the sequences from each library. Adaptor sequences and low quality sequence reads were removed prior to assembly. The assembly was run as a de novo, 454 EST project with accurate assembly and polyA/T clipping. Each library of contig assemblies from PS26 and $\mathrm{BC}_{8}$ was converted to a database and analyzed with the BlastN program provided by the RCC (Research Computing Center) at the University of Georgia http://rcc. uga.edu. The PS26 library contigs were chosen as queries and the $\mathrm{BC}_{8}$ library was chosen as the database. The BlastN analysis was performed with an E-value cutoff of $\leq \mathrm{e}^{-100}$. The BlastN output was parsed using an internal script such that only contigs with $100 \%$ identity over at least $100 \mathrm{bp}$ were selected for further analysis.

\section{BLAST analysis of the selected contigs}

BlastX was used to analyze sequences mapping to the ASGR-carrier chromosome by searching against the NCBI (National Center for Biotechnology Information, http://www.ncbi.nlm.nih.gov/) databases. A BlastN analysis was conducted on contigs without significant BlastX hits (e-value $\left.\leq \mathrm{e}^{-06}\right)$ to search for similar ESTs from other species. The most significant EST hit with an e-value of at least $\leq \mathrm{e}^{-20}$ was used for BlastX query to search for putative encoding proteins.

\section{Mapping of identical $\mathrm{PS} 26 / \mathrm{BC}_{8}$ contigs to the alien chromosome and/or ASGR}

Fasta files containing sequences from contigs with $100 \%$ identity over at least $100 \mathrm{bp}$ from both PS26 and $\mathrm{BC}_{8}$ libraries were generated. Alignment of each PS26/BC 8 contig pair yielded sixty-one assemblies of PS26/BC 8 contigs used as candidates for mapping to the ASGRcarrier chromosome. The $61 \mathrm{PS}^{26} / \mathrm{BC}_{8}$ contigs from were used as queries with BlastN against both the PS26 and $\mathrm{BC}_{8}$ MIRA-assembled databases at an E-value cutoff of $\leq \mathrm{e}^{-25}$. The BlastN results were parsed and used to help estimate the 'uniqueness' of the contig within the transcriptome. Primers were designed based on the overlapping region of PS26 and $\mathrm{BC}_{8}$ contigs, and in some cases included further 3' sequences for primer design if the contig was unique in both databases. When multiple contigs from each database showed high similarity to each other, primers were designed based on the region with the best polymorphisms to distinguish one from another. Primers were first tested for amplification with PS26, IA4X, N37 and 4 apomictic and 4 sexual plants from a segregating population of $\mathrm{BC}_{8}$. Primer pairs which did not amplify either IA $4 \mathrm{X}$ or sexual $\mathrm{BC}_{8}$ individuals were used for further screening with apomictic and sexual $F_{1} s$ to test for linkage to the ASGR.

For SSCP analysis a Bio-Rad Protean II system (BioRad Laboratories, Hercules, CA) was used to separate fragments in a $1 \mathrm{~mm}$ thick $12 \%$ non-denaturing PAGE gel with $10 \%$ glycerol. PCR product $(2 \mu \mathrm{l})$ was mixed with $10 \mu \mathrm{l}$ LIS loading dye ( $10 \%$ sucrose, $0.01 \%$ bromophenol blue, and $0.01 \%$ xylene cyanol FF), denatured at $98^{\circ} \mathrm{C}$ for $10 \mathrm{~min}$ and cooled to RT for at least $10 \mathrm{~min}$. Sample $(10 \mu \mathrm{l})$ was loaded and the gel was run in at 200 $\mathrm{V}$ for $20-22$ hours at $25^{\circ} \mathrm{C}$. Silver staining was used to detect the SSCP fragments.

\section{Expression patterns of transcripts mapped to the alien chromosome}

Total RNA was extracted from a panel of $\mathrm{BC}_{8}$ tissues including vegetative (leaf, root), and reproductive tissues 
at anthesis but before pollination (anther and ovary) with QIAGEN RNeasy ${ }^{\circledR}$ Plant Mini kit (QIAGEN, Valencia, CA) following the manufacturer's protocol. First-strand cDNA was synthesized following the manufacturer's protocol of First-strand cDNA Synthesis kit (Invitrogen, Carlsbad, CA). RT-PCR reactions were performed using primer pairs which mapped to the ASGRcarrier chromosome in a total volume of $20 \mu \mathrm{l}$ containing $1 \mu \mathrm{l}$ of first-strand cDNA, $1 \mu \mathrm{M}$ of each primer, $1 \mathrm{X}$ PCR buffer, $1.5 \mathrm{mM} \mathrm{MgCl}, 0.2 \mathrm{mM}$ dNTPs, and 1 unit of JumpStart ${ }^{\mathrm{TM}}$ Taq DNA polymerase (Sigma, St. Louis, MO). Amplification of contaminating genomic DNA was tested by the inclusion of controls that omitted the reverse transcriptase enzyme from the cDNA synthesis reaction, e.g. no $\mathrm{RT}$ controls. The PCR reaction was denatured at $94^{\circ} \mathrm{C}$ for $5 \mathrm{~min}$ followed by 35 cycles of $94^{\circ} \mathrm{C}$ denaturation for 30 seconds, annealing for $30 \mathrm{sec}-$ onds at respective temperatures, and $72^{\circ} \mathrm{C}$ extension for 1 min. RT-PCR products were separated on a $1.5 \%$ agarose gel and stained with ethidium bromide. Gel images were captured with the Molecular Imager Gel Doc XR System (Bio-Rad Laboratories).

\section{cDNA library construction}

Ovaries and anthers collected from apomictic $\mathrm{BC}_{8}$ around anthesis but prior to fertilization were frozen in liquid nitrogen. Total RNA was extracted with the RNeasy $^{\circledR}$ Plant Mini kit (QIAGEN) and then poly $\mathrm{A}^{+}$ RNA was purified from total RNA with Oligotex ${ }^{\circledR}$ mRNA Mini kit (QIAGEN) following the manufacturer's protocols. Yield of mRNA was quantified with a Nanodrop spectrophotometer (Thermo Fisher Scientific Inc., Wilmington, DE). mRNA was used for double-stranded cDNA synthesis with ZAP-cDNA ${ }^{\circledR}$ Synthesis Kit following the manufacturer's protocol (Stratagene, La Jolla, CA). Ligations, packaging, titering of the packaging reactions, and plaque lifts were conducted following the manufacturer's protocol of ZAP-cDNA ${ }^{(}$Gigapack $^{(}$III Gold Cloning Kit (Stratagene).

\section{cDNA library screening for target genes}

The apomictic $\mathrm{BC}_{8}$ ovary and anther-enriched cDNA library was screened with $\alpha-{ }^{32} \mathrm{P}$ labeled probes with transcripts mapping to the ASGR-carrier chromosome. The PCR fragments amplified from apomictic $\mathrm{BC}_{8}$ genomic DNA with the primers used for assigning a fragment to the ASGR-carrier chromosome were diluted and labeled with $\alpha-{ }^{32} \mathrm{P}$ by PCR in a total volume of 20 $\mu$ l. The labeling reaction contained $\sim 0.1 \mathrm{ng}$ primary PCR fragment, 1.25 unit Jumpstart Taq DNA polymerase (Sigma), $0.25 \mu \mathrm{M}$ of each primer, $0.5 \mathrm{mM} \mathrm{dATP} /$ $\mathrm{dTTP} / \mathrm{dGTP}$ mixture, $5 \mu \mathrm{l}$ of $\alpha-{ }^{32} \mathrm{P}$-labeled dCTP (3000 $\mathrm{Ci} / \mathrm{mmol})$ and $1 \times$ PCR buffer $(10 \mathrm{mM}$ Tris- $\mathrm{HCl}, 50$ $\mathrm{mM} \mathrm{KCl}, 1.5 \mathrm{mM} \mathrm{MgCl}{ }_{2}$ ). Probes were purified by passing through homemade Sephadex G-50 (Sigma) columns, which were assembled with Ultrafree ${ }^{\circledR}-\mathrm{MC}$ Centrifugal Filter Units (Millipore, Bedford, MA). Prehybridization of the membranes in hybridization buffer (0.5 M sodium phosphate, 7\% SDS, $1 \mathrm{mM}$ EDTA, pH $8.0)$ containing $0.1 \mathrm{mg} \mathrm{ml}^{-1}$ salmon sperm DNA, which was denatured in boiling water for 10 minutes and cooled on ice before adding to the hybridization solution, was conducted at $65^{\circ} \mathrm{C}$ for $4 \mathrm{~h}$ before addition of the labeled, denatured probe. Hybridization was conducted at $65^{\circ} \mathrm{C}$ overnight followed by three washes at the same temperature for $30 \mathrm{~min}$ each with the following buffers: 1) $1 \times$ SSC, $0.1 \%$ SDS; 2) $0.5 \times$ SSC, $0.1 \%$ SDS; 3$) 0.1 \times$ SSC, $0.1 \%$ SDS. After the final wash, membranes were wrapped with plastic film and exposed to $\mathrm{x}$-ray film overnight at $-80^{\circ} \mathrm{C}$ prior to manually developing with Kodak ${ }^{\circledR}$ GBX Developer and Fixer (Thermo Fisher Scientific Inc). Autoradiographs were aligned with the respective plates to recover hybridizing plaques with sterile glass pipettes. Recovered plaques were released in tubes containing $1.0 \mathrm{ml} \mathrm{SM}$ phage buffer (according to the formula in the manual of ZAPcDNA $^{\circledR}$ Gigapack $^{\circledR}$ III Gold Cloning Kit) and $20 \mu \mathrm{l}$ chloroform (Sigma). After overnight elution at $4^{\circ} \mathrm{C}, 1 \mu \mathrm{l}$ SM buffer of each recovered sample was used for PCR to verify positive signals. Since the primary screening was carried out with a high density of plaque clones, the recovered positive plaques were purified after secondary and tertiary screens at much lower densities. Single plaques showing positive hybridization signals were recovered in $500 \mu \mathrm{l} \mathrm{SM}$ buffer with $10 \mu \mathrm{l}$ chloroform (Sigma) at $4^{\circ} \mathrm{C}$.

\section{Sequencing and mapping of candidate CDNA clones to the ASGR}

In vivo excision of single plaque clones was conducted using ExAssist ${ }^{\circledR}$ helper phage with SOLR $^{\circledR}$ strain following the protocol in the manual of ZAP-cDNA ${ }^{\circledR}$ Gigapack ${ }^{\circledR}$ III Gold Cloning Kit (Stratagene). Single colonies containing the pBluescript double-stranded phagemid with the cloned CDNA insert were isolated and cultured in liquid Luria-Bertani (LB) medium containing $100 \mu \mathrm{g}$ $\mathrm{mL}^{-1}$ ampicillin at $37^{\circ} \mathrm{C}$ overnight. An aliquot of each culture was further grown in freeze broth containing $100 \mu \mathrm{g} \mathrm{mL} \mathrm{m}^{-1}$ ampicillin at $37^{\circ} \mathrm{C}$ overnight and then stored at $-80^{\circ} \mathrm{C}$ before sending out for sequencing. Sequencing was conducted with M13 primers (Georgia Genomics Facility, Athens, GA). Vector and bad quality sequences were trimmed from the original sequences with VectorNTI Advanced 10 (Invitrogen) and primers were designed with VectorNTI using the high quality cDNA sequences. Primers were then tested with apomictic and sexual $F_{1} s$ for linkage to the ASGR as described above. 


\section{Blast2GO}

Annotation for each library was performed using Blast2GO software, http://www.blast2go.org/start_blast2go [39]. BlastX (database: GenBank nr/E-value cutoff: $\mathrm{e}^{-06}$ ), GO term mapping (default values) and Annotation (database: b2g-2009 with default values) were used. Annotations were validated and augmented using ANNEX. Libraries were compared using the Fisher's exact test with FDR value of $\leq 0.01$ or $\leq 0.05$.

\section{Additional material}

Additional file 1: PS26_MIRA.fasta. A fasta file containing the MIRA assembled contigs of the PS26 ovule transcriptome.

Additional file 2: BC8_MIRA.fasta. A fasta file containing the MIRA assembled contigs of the $\mathrm{BC}_{8}$ ovule transcriptome.

Additional file 3: Table S1 - Primers designed for mapping transcripts to the ASGR-carrier chromosome. Microsoft word file: ASGR-Carrier Chromosome transcript primers.doc contains a table with primer sequences used for experiments to map ovule transcripts to the ASGR-carrier chromosome and the ASGR locus with annealing temperatures.

\section{Acknowledgements}

We thank Dr. Wayne Hanna for providing plant materials, Virgil Ed Johnson for bioinformatics assistance, and Evelyn P. Morgan for technical support. This work was funded by the National Science Foundation (award no. 0115911).

\section{Authors' contributions}

YZ and JC performed the sequence analysis. $Y Z$ collected and prepared CDNA samples for 454 sequencing. YZ and JC mapped transcripts and did expression analysis. JC performed the Blast2 $\mathrm{GO}$ analysis. PO-A provided guidance for the study. All authors have read and approved the manuscript.

Received: 13 January 2011 Accepted: 26 April 2011

Published: 26 April 2011

\section{References}

1. Nogler GA: Gametophytic apomixis. In Embryology of Angisoperms. Edited by: Johri BM. Springer-Verlag, Berlin; 1984:475-518.

2. Koltunow AM: Apomixis: Embryo Sacs and Embryos Formed without Meiosis or Fertilization in Ovules. Plant Cell 1993, 5:1425-1437.

3. Grimanelli D, Leblanc O, Perotti E, Grossniklaus U: Developmental genetics of gametophytic apomixis. Trends Genet 2001, 17:597-604

4. Hanna WW: Use of apomixis in cultivar development. Adv Agron 1995, 54:333-350.

5. Koltunow AM, Bicknell RA, Chaudhury AM: Apomixis: Molecular Strategies for the Generation of Genetically Identical Seeds without Fertilization. Plant Physiol 1995, 108:1345-1352.

6. Savidan Y: Apomixis: genetics and breeding. Plant Breed Rev 2000, 18:13-85.

7. van Dijk P, van Damme J: Apomixis technology and the paradox of sex. Trends Plant Sci 2000, 5:81-84.

8. Carman JG: Asynchronous expression of duplicate genes in angiosperms may cause apomixis, bispory, tetraspory, and polyembryony. Biol J Linn Soc 1997, 61:51-94

9. Bicknell RA, Koltunow AM: Understanding apomixis: recent advances and remaining conundrums. Plant Cell 2004, 16(Suppl):S228-245.

10. Ozias-Akins P: Apomixis: Developmental Characteristics and Genetics. Critical Reviews in Plant Sciences 2006, 25:199-214.

11. Ozias-Akins $P$, Roche D, Hanna WW: Tight clustering and hemizygosity of apomixis-linked molecular markers in Pennisetum squamulatum implies genetic control of apospory by a divergent locus that may have no allelic form in sexual genotypes. Proc Natl Acad Sci USA 1998, 95:5127-5132.

12. Goel S, Chen Z, Conner JA, Akiyama Y, Hanna WW, Ozias-Akins P: Delineation by fluorescence in situ hybridization of a single hemizygous chromosomal region associated with aposporous embryo sac formation in Pennisetum squamulatum and Cenchrus ciliaris. Genetics 2003, 163:1069-1082.

13. Akiyama Y, Conner JA, Goel S, Morishige DT, Mullet JE, Hanna WW, OziasAkins P: High-resolution physical mapping in Pennisetum squamulatum reveals extensive chromosomal heteromorphism of the genomic region associated with apomixis. Plant Physiol 2004, 134:1733-1741.

14. Leblanc O, Armstead I, Pessino SC, Ortiz JP, Evans C, Valle CD, Hayward MD: Non-radioactive mRNA fingerprinting to visualize gene expression in mature ovaries of Brachiaria hybrids derived from B. brizantha, an apomictic tropical forage. Plant Science 1997, 126:49-58.

15. Rodrigues JC, Cabral GB, Dusi DM, de Mello LV, Rigden DJ, Carneiro VT: Identification of differentially expressed CDNA sequences in ovaries of sexual and apomictic plants of Brachiaria brizantha. Plant Mol Biol 2003, 53:745-757.

16. Pessino SC, Espinoza F, Martinez EJ, Ortiz JP, Valle EM, Quarin CL: Isolation of cDNA clones differentially expressed in flowers of apomictic and sexual Paspalum notatum. Hereditas 2001, 134:35-42.

17. Laspina NV, Vega T, Seijo JG, Gonzalez AM, Martelotto LG, Stein J, Podio M, Ortiz JPA, Echenique VC, Quarin CL, Pessino SC: Gene expression analysis at the onset of aposporous apomixis in Paspalum notatum. Plant Mol Biol 2008, 67:615-628.

18. Polegri L, Calderini O, Arcioni S, Pupilli F: Specific expression of apomixislinked alleles revealed by comparative transcriptomic analysis of sexual and apomictic Paspalum simplex Morong flowers. J Exp Bot 2010, 61:1869-1883.

19. Albertini E, Marconi G, Barcaccia G, Raggi L, Falcinelli M: Isolation of candidate genes for apomixis in Poa pratensis L. Plant Mol Biol 2004 56:879-894.

20. Albertini E, Marconi G, Reale L, Barcaccia G, Porceddu A, Ferranti F, Falcinelli M: SERK and APOSTART. Candidate genes for apomixis in Poa pratensis. Plant Physiol 2005, 138:2185-2199.

21. Chen L, Miyazaki C, Kojima A, Saito A, Adachi T: Isolation and characterization of a gene expressed during early embryo sac development in apomictic guinea grass (Panicum maximum). J Plant Physiol 1999, 154:55-62.

22. Chen L, Guan L, Seo M, Hoffmann F, Adachi T: Developmental expression of ASG- 1 during gametogenesis in apomictic guinea grass (Panicum maximum). J Plant Physiol 2005, 162:1141-1148.

23. Yamada-Akiyama H, Takahara M, Kikuchi S, Takamiza T, Nakagawa H, Sugita Si, Kishimoto N, Ebina M, Akiyama Y, Xu Q, Yazaki J, Tsuruta Si: Analysis of expressed sequence tags in apomictic guineagrass (Panicum maximum). J Plant Physiol 2009, 166:750-761.

24. Vielle-Calzada JP, Nuccio ML, Budiman MA, Thomas TL, Burson BL, Hussey MA, Wing RA: Comparative gene expression in sexual and apomictic ovaries of Pennisetum ciliare (L.) Link. Plant Mol Biol 1996, 32:1085-1092.

25. Singh M, Burson BL, Finlayson SA: Isolation of candidate genes for apomictic development in buffelgrass (Pennisetum ciliare). Plant Mol Biol 2007, 64:673-682.

26. Sharbel TF, Voigt ML, Corral JM, Thiel T, Varshney A, Kumlehn J, Vogel H, Rotter B: Molecular signatures of apomictic and sexual ovules in the Boechera holboellii complex. Plant J 2009, 58:870-882.

27. Sharbel TF, Voigt ML, Corral JM, Galla G, Kumlehn J, Klukas C, Schreiber F, Vogel H, Rotter B: Apomictic and sexual ovules of Boechera display heterochronic global gene expression patterns. Plant Cell 2010, 22:655-671.

28. Ozias-Akins P, van Dijk PJ: Mendelian genetics of apomixis in plants. Annu Rev Genet 2007, 41:509-537.

29. Dujardin M, Hanna WW: Cytogenetics of double cross hybrids between Pennisetum americanum $-P$. purpureum amphiploids and $P$. americanum $\mathrm{X}$ Pennisetum squamulatum interspecific hybrids. Theoretical and Applied Genetics 1984, 69:97-100.

30. Dujardin M, Hanna WW: Developing apomictic pearlmilletcharacterization of a BC 3 plant. J Genet Breed 1989, 43:145-151.

31. Singh $M$, Conner JA, Zeng $Y$, Hanna $W W$, Johnson VE, Ozias-Akins $P$ : Characterization of apomictic $\mathrm{BC}_{7}$ and $\mathrm{BC}_{8}$ pearl millet: Meiotic 
chromosome behavior and construction of an ASGR-carrier chromosome-specific library. Crop Science 2010, 50:892-902.

32. Droege M, Hill B: The Genome Sequencer FLX System-longer reads, more applications, straight forward bioinformatics and more complete data sets. J Biotechnol 2008, 136:3-10

33. Emrich SJ, Barbazuk WB, Li L, Schnable PS: Gene discovery and annotation using LCM-454 transcriptome sequencing. Genome Res 2007, 17:69-73.

34. Jones-Rhoades MW, Borevitz JO, Preuss D: Genome-wide expression profiling of the Arabidopsis female gametophyte identifies families of small, secreted proteins. PLoS Genet 2007, 3:1848-1861.

35. Vera JC, Wheat CW, Fescemyer HW, Frilander MJ, Crawford DL, Hanski I, Marden $\mathrm{JH}$ : Rapid transcriptome characterization for a nonmodel organism using 454 pyrosequencing. Mol Ecol 2008, 17:1636-1647.

36. Guo SG, Zheng Y, Joung JG, Liu SQ, Zhang ZH, Crasta OR, Sobral BW, Xu Y, Huang SW, Fei ZJ: Transcriptome sequencing and comparative analysis of cucumber flowers with different sex types. BMC Genomics 2010, 11:384.

37. Sun C, Li Y, Wu Q, Luo HM, Sun YZ, Song JY, Lui EMK, Chen SL: De novo sequencing and analysis of the American ginseng root transcriptome using a GS FLX Titanium platform to discover putative genes involved in ginsenoside biosynthesis. BMC Genomics 2010, 11:262

38. Chevreux B, Pfisterer T, Drescher B, Driesel AJ, Muller WE, Wetter T, Suhai S: Using the miraEST assembler for reliable and automated mRNA transcript assembly and SNP detection in sequenced ESTs. Genome Res 2004, 14:1147-1159.

39. Conesa A, Götz S, García-Gómez JM, Terol J, Manuel Talón M, Robles M: Blast2GO: a universal tool for annotation, visualization and analysis in functional genomics research. Bioinformatics 2005, 21(18):3674-3676.

40. Bluthgen N, Brand K, Cajavec B, Swat M, Herzel H, Beule D: Biological profiling of gene groups utilizing gene ontology. Genome Inform 2005, 16(1):106-115.

41. Malik MR, Wang F, Dirpaul JM, Zhou N, Polowick PL, Ferrie AM, Krochko JE: Transcript profiling and identification of molecular markers for early microspore embryogenesis in Brassica napus. Plant Physiol 2007, 144:134-154.

42. Spencer MW, Casson SA, Lindsey K: Transcriptional profiling of the Arabidopsis embryo. Plant Physiol 2007, 143:924-94.

43. Hoecker N, Keller B, Muthreich N, Chollet D, Descombes P, Piepho HP, Hochholdinger F: Comparison of maize (Zea mays L.) F1-hybrid and parental inbred line primary root transcriptomes suggests organ-specific patterns of nonadditive gene expression and conserved expression trends. Genetics 2008, 179:1275-1283.

44. Morozova O, Marra MA: Applications of next-generation sequencing technologies in functional genomics. Genomics 2008, 92:255-264.

45. Cheung F, Haas BJ, Goldberg SM, May GD, Xiao Y, Town CD: Sequencing Medicago truncatula expressed sequenced tags using 454 Life Sciences technology. BMC Genomics 2006, 7:272.

46. Ohtsu K, Smith MB, Emrich SJ, Borsuk LA, Zhou R, Chen T, Zhang X, Timmermans MC, Beck J, Buckner B, Janick-Buckner D, Nettleton D, Scanlon MJ, Schnable PS: Global gene expression analysis of the shoot apical meristem of maize (Zea mays L.). Plant J 2007, 52:391-404.

47. Barbazuk WB, Emrich SJ, Chen HD, Li L, Schnable PS: SNP discovery via 454 transcriptome sequencing. Plant J 2007, 51:910-918.

48. Torres TT, Metta M, Ottenwalder B, Schlotterer C: Gene expression profiling by massively parallel sequencing. Genome Res 2008, 18:172-177.

49. Bekal S, Craig JP, Hudson ME, Niblack TL, Domier LL, Lambert KN: Genomic DNA sequence comparison between two inbred soybean cyst nematode biotypes facilitated by massively parallel 454 micro-bead sequencing. Mol Genet Genomics 2008, 279:535-543.

50. Conner JA, Goel S, Gunawan G, Cordonnier-Pratt MM, Johnson VE, Liang C, Wang H, Pratt LH, Mullet JE, Debarry J, Yang L, Bennetzen JL, Klein PE, Ozias-Akins P: Sequence Analysis of Bacterial Artificial Chromosome Clones from the Apospory-Specific Genomic Region of Pennisetum and Cenchrus. Plant Physiol 2008, 147(3):1396-1411.

51. Young BA, Sherwood RT, Bashaw EC: Cleared-pistil and thicksectioning techniques for detecting aposporous apomixis in grasses. Can J Bot 1979, 57:1668-1672.

52. Nakazono M, Qiu F, Borsuk LA, Schnable PS: Laser-capture microdissection, a tool for the global analysis of gene expression in specific plant cell types: identification of genes expressed differentially in epidermal cells or vascular tissues of maize. Plant Cell 2003, 15:583-596. doi:10.1186/1471-2164-12-206

Cite this article as: Zeng et al.: Identification of ovule transcripts from the Apospory-Specific Genomic Region (ASGR)-carrier chromosome. BMC Genomics 2011 12:206.

\section{Submit your next manuscript to BioMed Central and take full advantage of:}

- Convenient online submission

- Thorough peer review

- No space constraints or color figure charges

- Immediate publication on acceptance

- Inclusion in PubMed, CAS, Scopus and Google Scholar

- Research which is freely available for redistribution 